\title{
Brain drain and the disenchantment of being a higher education student in Portugal
}

\author{
Luísa Cerdeiraa, Maria de Lourdes Machado-Taylor ${ }^{\mathrm{b}}$, Belmiro Cabrito ${ }^{\mathrm{a}}$, \\ Tomás Patrocínio ${ }^{a}$, Rui Brites ${ }^{c^{*}}$, Rui Gomes ${ }^{\mathrm{d}^{*}}$, João Teixeira Lopes ${ }^{\mathrm{e}}$, Henrique Vaz ${ }^{\mathrm{f}}$, \\ Paulo Peixotog, Dulce Magalhães ${ }^{\mathrm{e}}$, Sílvia Silva ${ }^{\mathrm{e}^{*}}$ and Rafaela Ganga ${ }^{\mathrm{e}}$ \\ anstitute of Education, University of Lisbon, Lisbon, Portugal; ${ }^{b} \mathrm{CIPES}$, Centre for Research in Higher \\ Education Policies, Matosinhos, Portugal; ' ISEG, School of Economics and Management, University of \\ Lisbon, Lisbon, Portugal; ${ }^{d}$ CES, Centre for Social Studies, University of Coimbra, Coimbra, Portugal; \\ eFaculdade de Letras, University of Porto, Porto, Portugal; ${ }^{\mathrm{f} F a c u l d a d e}$ de Psicologia e de Ciências da \\ Educação, University of Porto, Porto, Portugal; ${ }^{9}$ Faculdade de Economia, Colégio de S. Jerónimo, University \\ of Coimbra, CES, Coimbra, Portugal
}

\begin{abstract}
The efforts made by most countries to accelerate economic development have included a significant investment in education. It has been argued that investment in education, particularly higher education, was itself a potential factor in economic development. Education has become a relatively easy means of improving access to the labour market. However, in Portugal, the recent trend has been reversed, and the country now faces a growing number of university graduates in several fields of education and training that do not have a job based on their formal qualifications. Despite the differences of unemployment by area of education and training, unemployment of the young skilled has been a problem in recent years. Therefore, following this unemployment trend, there has been growing the exodus of highly skilled professionals from the Portuguese economy, leaving it with a reduced supply of skilled people. This article discusses the employability of graduates from several academic areas and discusses the educational and economic policies that generate a real brain drain.
\end{abstract}

\section{KEYWORDS}

Brain drain; employability; higher education; Portugal; students

\section{Introduction}

Education has always taken a range of forms in time and space, chasing goals and objectives across human societies. Structured around its actors - the apprentice and the master; the student and the teacher; the trainee and the trainer - education as a socially constructed entity is influenced by social changes. Those changes are thus a consequence of ideological, material and social conditions in which education is provided and the role that society is committed to it. Education should contribute to the acquisition, development and transmission of knowledge, shaping individual and 
collective ways of thinking and acting, guaranteeing the development of individuals and societies.

However, in the current mass production society, the function of 'school' has changed. Today, it is expected that the school will not only contribute to the development of citizenship but most particularly that it will 'produce' socially useful citizens, that is, citizens able to enter the labour market and respond to the requests that this imposes. Education must produce individuals able to be in a constant state of employability.

Therein lies one of the great current debates about education and its mission, and simultaneously one of the most important decisions that young people have to make: what to study in a context of global market demands marked by expressions that are part of the liberal grammar such as individualism, human capital, competition, competitiveness, flexibility, investment and employability.

One constant problem faced by youth, but one of utmost importance given the economic recession and jobs crisis, is to decide on the exact academic route to follow. In the 1970s, Boudon (1973) warned of a diverse set of factors influencing decisionmaking about study, among which he emphasised social heritage. In turn, authors such as Bourdieu and Passeron $(1964,1970)$ discussed the role of the school in the construction of inequalities and social reproduction. For other authors, the reproductive role of the school is so visible that the children of the 'working class' get the 'working class' jobs (Willis, 1977). Prost (1992) also warns that school democratisation has transferred the reproduction of social inequalities to the university level, in the sense that certain study areas are directly linked to certain forms of social capital. Moreover, in Portugal, studies from Cabrito (2002), Cerdeira (2009), and Cerdeira, Cabrito, Patrocínio, Machado, and Brites (2012) clearly demonstrate the educational trajectories of young people enrolled in higher education and their relationship with economic and cultural capital: the various ranks in higher education attract individuals with specific characteristics and capital.

In the debate about the role of the university, another point of view has developed with social scientists such as Burton Clark (1998) and Mora and Nugent (1998) advocating a greater connection between the university and the market as a means to ensure greater employability of new graduates of higher education.

In these circumstances, the concerns of young people about their future as students are understandable. What to study? Deciding whether to study humanities, technology, behavioural sciences, management sciences or life sciences is a complex process which influences the way young people enter the labour market (Martínez, Mora, \& Vila, 2007; Nugent, 2004). So increasingly, the student must ask questions about their future in terms of training: which discipline areas are more employable? Searching for work in their home country or abroad?

However, reading the curricula of the programmes offered by higher education institutions or listening to the advice of businessmen and politicians are not sufficient to enable students to make good decisions. In fact, students are in a situation of contradictory information so they may be 'misguided' because of the influence that competition between educational institutions and marketing on one hand and the rhetoric of politicians and businessmen on the other can have on their decision-making capacity. Consequently, the social origin and cultural capital of the student, institutional 
marketing and business and governmental information are some of the many factors that are always present in student decision-making.

In recent years, young people in Portugal and in other countries are being 'helped' in that selection process through information, including the employability of higher education programmes measured by the rate of graduates entering the job market. One of the aims of this article is to discuss employability, paying attention to the latest official data on the employability of the graduates from the various academic areas of higher education in Portugal (DGEEC/MEC, as cited in Cardoso et al., 2012).

One relevant observation is that even good higher education performance by graduates has no guarantee of employment, particularly in the depressed economic situation currently being experienced by Portugal. In these circumstances, seeking employment abroad has become an alternative for young graduates. Searching for a job thus appears as one of the reasons used to explain the brain drain from the country, although there are certainly other reasons. Understanding this phenomenon is the aim of the research project that the authors are conducting concerning brain drain.

For this paper, analysis has assumed that skilled emigration is based on one of two contrasting models: (a) the model of the exodus that stresses the idea that more skilled individuals are forced into exile to allow them to get a job and remuneration corresponding to their training and (b) the model of the diaspora that stresses the mutual benefits of intercultural exchanges opened by the circulation of academic, scientific and cultural cosmopolitan elites. This research aims to test the relevance of each of these models, referencing the various types of mobility demonstrated by highly qualified Portuguese professionals to the rest of Europe in the last decade. It has been recognised in international studies published over recent years that Portugal is one of the European countries where the drain is more accentuated in the last decade. The percentage of skilled emigration estimated by Docquier and Marfouk (2006) in 2000 for Portugal is 19.5 per cent (compared with other European referenced countries: United Kingdom 16.7 per cent, Slovakia 16.7 per cent; Sweden 4.3 per cent, Spain 4.3 per cent and France 3.4 per cent).

The research for this paper is based on a mixed strategy which makes use of quantitative and qualitative data collections: questionnaire surveys (1011 valid responses); life stories (53 individuals were interviewed); and interviews with focus groups (seven focus groups were formed, comprising 27 people). Using a multiple case methodology, we have described and compared the circumstances, the modalities and the characteristics of the mobility of two types of migration of high-skilled Portuguese nationals in Europe: (a) long-term migration to a European country for work in primary or secondary segment of the employment system; (b) temporary or commuting mobility through European networks of science, production, services or culture.

Our hypothesis assumes that the different migration flows as well as the contexts, projects, the paths of life and how biographical expectations are constructed and therefore can be understood by the concurrent models. Case studies of each of these groups have been used to test the research hypotheses presented in the literature in a comparative way:

(a) The hypothesis of brain drain. Since human capital is not made profitable in the society or country in which it was generated, the brain drain results in a subsidy 
to the rich countries (Hamilton, 2003) because the growth of most developed countries also stems from the concentration of human capital (Castles \& Miller, 2003).

(b) The hypothesis of a beneficial brain drain. Some empirical studies concerning investments in human capital by the growth rate of the proportion of tertiary educated individuals have found that the brain drain rate measured in the base period exerts a positive effect on the rate of change of the previous stock of human capital, interpreted as a brain gain (Beine, Docquier, \& Rapoport, 2003, 2008; Docquier, Faye, \& Pestieau, 2008). On the contrary, Heuer (2011), modelling anticipatory expectation-building and accounting for possible convergence forces in the accumulation process of human capital, reveals a strong negative effect of the occupation-specific emigration rates on the sending countries employment shares, which suggests an inexistent brain gain compared to the brain drain.

(c) The hypothesis of the cross-fertilisation movement of elites. Since the international mobility of skilled human resources is often transitory and takes on characteristics of exchange of knowledge, skills and temporary projects, this circular process is beneficial for both developed countries and developing countries (Olesen, 2002).

(d) The hypothesis of brain circulation by creating networks. The networks formed by the scientific diaspora and business have frequently sought to use the knowledge and skills acquired by scientists and other expatriate professionals in the development of the country of origin (Meyer, 2001).

(e) The hypothesis of latent brain drain due to mobility training. As mobility training for graduate or postgraduate students has worsened in the last decade, the outputs to study abroad, with or without grants, originally planned as temporary, may become permanent if those studying abroad enter the labour market of developed countries or countries less affected by youth unemployment (Pizarro, 2005). However, there is also evidence that a period of study abroad, followed by work experience in the destination country can become a mediumterm benefit when the person returns (Johnson \& Regets, 1998).

The selection of the case studies follows the intersection of four main structuring principles: (a) Time characteristics of mobility: permanent or temporary, long term or transitory; (b) Social place in the employment system: primary segment or secondary segment of the labour market; (c) Functional profile in the employment system: academic and scientist, other highly skilled professions and (d) Type of mobility: direct (after having entered in the employment system of the sending country), indirect or latent (after a period of study in the receiving country).

In this framework, the objectives of this article are:

(a) to present and discuss employability rates of different higher education discipline areas

(b) to submit emigration rates of skilled young labour by discipline area

(c) to present the preliminary findings of the project that can be drawn from the focus group interviews. 


\section{Skills and unemployment}

One of the strongest relationships that is usually recorded between qualifications and employment is that the level of qualifications directly favours the inclusion of individuals in the labour market. The table below is testimony to this:

In an analysis of the data in Table 1, one notices that the unemployment rate of individuals under 40 years of age has increased in the period under review. Indeed it is worth noting that the unemployment rate of this group of individuals more than doubled between 2002 and 2010, from 6.63 per cent to 13.23 per cent

However, the unemployment rates for individuals under 40 years of age without higher education more than doubled (increasing from 6.65 per cent in 2002 to 14.44 per cent in 2010), while the unemployment rate of individuals with higher education increased by 'only' 36.3 per cent in the period under review.

The above data show, therefore, a greater likelihood of staying in employment for individuals with higher qualifications. In fact, and despite annual fluctuations, the trend has been an increase in the unemployment rate for individuals without higher education and a decrease in that rate for individuals with higher education. The market continues the trend of the last century to reward higher education, a clear 'obedience' to the assumptions of the theory of human capital (Becker, 1964; Schultz, 1961).

From the data in Table 2, it can be seen that the unemployment rate increased over the last years, both with and without higher education degrees. But the unemployment rate of individuals 'with higher education degree' is still the lowest.

Table 1. Portuguese unemployment rate for individuals under 40 years, according to educational attainment (percentage).

\begin{tabular}{cccr} 
Year & $\begin{array}{c}\text { With a higher } \\
\text { education degree }\end{array}$ & $\begin{array}{c}\text { Without a higher } \\
\text { education degree }\end{array}$ & Total \\
\hline 2002 & 6.42 & 6.65 & 6.63 \\
2003 & 7.70 & 8.47 & 8.36 \\
2004 & 7.31 & 8.57 & 8.37 \\
2005 & 8.74 & 9.77 & 9.61 \\
2006 & 8.95 & 9.67 & 9.55 \\
2007 & 10.59 & 10.12 & 10.20 \\
2008 & 9.31 & 9.50 & 9.46 \\
2009 & 8.21 & 12.65 & 11.77 \\
2010 & 8.75 & 14.44 & 13.23 \\
\hline
\end{tabular}

Source: INE, IE - National Institute of Statistics.

Table 2. Portuguese unemployment rate according to educational attainment (percentage).

\begin{tabular}{cccr}
\hline Wear & $\begin{array}{c}\text { With higher } \\
\text { education degree }\end{array}$ & $\begin{array}{c}\text { Without higher education } \\
\text { degree (but completed } \\
\text { high school) }\end{array}$ & Total \\
\hline 2007 & 7.50 & 8.20 & 8.00 \\
2008 & 6.90 & 7.90 & 7.60 \\
2009 & 6.40 & 9.60 & 9.50 \\
2010 & 7.10 & 11.30 & 10.80 \\
2011 & 9.20 & 13.30 & 12.70 \\
2012 & 11.90 & 17.60 & 15.70 \\
\hline
\end{tabular}

Source: INE, IE - National Institute of Statistics; Pordata. 
Table 3. Portuguese unemployment rate for individuals under 40 years, according to the degree (percentage).

\begin{tabular}{ccccrr}
\hline Year & $\begin{array}{c}\text { Higher education } \\
- \text { bachelor* }\end{array}$ & $\begin{array}{c}\text { Higher education } \\
-1 \text { st cycle }\end{array}$ & $\begin{array}{c}\text { Higher education } \\
-2 \text { 2nd cycle }\end{array}$ & PhD & Total \\
\hline 2002 & 5.50 & 6.70 & 6.80 & 1.26 & 6.42 \\
2003 & 6.12 & 8.42 & 3.12 & 0.00 & 7.70 \\
2004 & 6.23 & 7.64 & 6.57 & 0.00 & 7.31 \\
2005 & 8.09 & 9.17 & 2.21 & 2.39 & 8.74 \\
2006 & 8.36 & 9.19 & 8.12 & 0.00 & 8.95 \\
2007 & 10.09 & 10.87 & 4.89 & 12.26 & 10.59 \\
2008 & 6.86 & 9.56 & 11.36 & 3.98 & 9.31 \\
2009 & 7.13 & 8.60 & 4.10 & 0.00 & 8.21 \\
2010 & 11.24 & 9.02 & 4.43 & 2.44 & 8.75 \\
\hline
\end{tabular}

Source: INE, IE - National Institute of Statistics. ${ }^{*}$ Corresponding to a polytechnic degree, up to 3 years of higher education studies, which refers to the Portuguese higher education system before the introduction of the Bologna Process.

In addition to these findings, and because higher education includes various grade levels, Table 3 presents the unemployment rates for individuals under 40 years of age by the level of degree held.

As can be seen in Table 3, despite the fluctuations in unemployment rates in each subgroup of individuals, while the unemployment rate for individuals with a bachelor degree and higher education - 1st cycle has increased over the time period, the corresponding rates for individuals with masters and doctorates declined. The data analysis allows us to infer that the market values higher-level academic degrees more, especially doctoral degrees, revealing that higher-level credentials allow degree holders better access to the labour market (Spence, 1973).

Combined analysis of Tables 1-3 validates the premise that education is an important factor in finding and keeping a job, as postulated in human capital theories.

\section{Areas of training and unemployment}

As there are multiple areas of education and training, it is natural that not all graduates have the same experiences with the labour market. That is, taking into account the 'needs' of the market is that the market can 'treat' graduates differently in each area, explaining the differences among unemployment rates by scholarly area. As Collins (1979) has stated, qualifications are no longer the only thing that graduates need to negotiate their entry into the labour market. The data in Table 4 demonstrate the unequal treatment of areas of study by the market in Portugal in the last decade.

By analysing the data in Table 4 it can be observed, first, that the unemployment rate of individuals aged 40 years in some of the training areas is, on average, higher than the overall average rate. So it is with the areas of training of teachers/trainers and educational sciences, arts and humanities, social sciences, business and law, life sciences, physical sciences and services. It is curious to note that the highest rates of unemployment are those related to the teaching profession (teachers of languages, arts, biology and physics). At the opposite end, there are the areas related to computers, mathematics and statistics, in fact those areas most related to information and communications technology development. 
Table 4. Portuguese unemployment rates for individuals aged less than 40 years, according to the area of education and training (in percentage).

\begin{tabular}{|c|c|c|c|c|c|}
\hline Area of education and training & 2004 & 2006 & 2008 & 2010 & Average (2004-2010) \\
\hline Training of teachers/trainers and education science & 7.62 & 10.67 & 6.98 & 7.34 & 9.05 \\
\hline Arts and humanities & 8.82 & 11.83 & 14.22 & 11.51 & 12.44 \\
\hline Foreign languages and literatures & 10.09 & 12.43 & 17.46 & 3.94 & 11.33 \\
\hline Social sciences, business and law & 8.38 & 7.73 & 9.19 & 1018 & 9.00 \\
\hline Life sciences & 8.31 & 11.66 & 15.82 & 8.90 & 11.06 \\
\hline Physical sciences & 14.80 & 15.01 & 6.35 & 6.38 & 10.83 \\
\hline Mathematics and statistics & 14.78 & 7.74 & 3.78 & 2.94 & 7.28 \\
\hline Computer science & 3.40 & 6.02 & 2.83 & 5.60 & 3.39 \\
\hline Computer science - user's perspective & 7.42 & 8.36 & 12.08 & 6.09 & 7.01 \\
\hline Engineering, manufacturing and construction & 4.58 & 7.29 & 7.35 & 7.80 & 7.68 \\
\hline Agriculture, forestry, fisheries and veterinary science & 6.48 & 2.21 & 5.37 & 11.81 & 7.64 \\
\hline Health and social protection & 3.13 & 6.52 & 9.23 & 7.32 & 6.40 \\
\hline Services & 5.17 & 15.11 & 7.09 & 13.77 & 10.90 \\
\hline Large group: science, mathematics and computing & 8.28 & 19.21 & 0.00 & 0.00 & 3.54 \\
\hline Unknown & 0.00 & 11.68 & 5.78 & 12.25 & 8.72 \\
\hline Total & 7.31 & 8.95 & 9.31 & 8.75 & 8.86 \\
\hline
\end{tabular}

Source: INE, IE - National Institute of Statistics.

Table 5. Portuguese working abroad with higher qualifications, according the area of education and training (in percentage).

\begin{tabular}{lrrrrr}
\hline Area of education and training & 2004 & 2006 & 2008 & 2010 & Average (2004-2010) \\
\hline Training of teachers/trainers and education science & 100 & 11.3 & 8.6 & 13.6 & 13.0 \\
Arts and humanities & 8.1 & 13.0 & 0.0 & 3.4 & 10.4 \\
Foreign languages and literatures & 3.6 & 4.3 & 2.6 & 5.1 & 3.9 \\
Social sciences, business and law & 25.8 & 24.3 & 33.6 & 25.2 & 24.9 \\
Life sciences & 0.0 & 0.0 & 4.4 & 4.0 & 2.9 \\
Physical sciences & 3.1 & 0.0 & 3.9 & 16.1 & 4.8 \\
Mathematics and statistics & 0.0 & 0.0 & 0.0 & 0.0 & 0.0 \\
Computer science & 0.0 & 0.0 & 9.2 & 0.0 & 1.4 \\
Computer science - user's perspective & 0.0 & 0.0 & 0.0 & 0.0 & 0.0 \\
Engineering, manufacturing and construction & 48.6 & 47.2 & 30.3 & 17.0 & 28.6 \\
Agriculture, forestry, fisheries and veterinary science & 0.0 & 0.0 & 0.0 & 0.9 & 0.2 \\
Health and social protection & 0.9 & 0.0 & 5.6 & 5.3 & 5.1 \\
Services & 0.0 & 0.0 & 1.9 & 6.7 & 3.9 \\
Large group: science, mathematics and computing & 0.0 & 0.0 & 0.0 & 2.6 & 0.5 \\
Unknown & 0.0 & 0.0 & 00 & 0.0 & 0.4 \\
\hline
\end{tabular}

Source: INE, IE - National Institute of Statistics.

\section{Areas of training and work abroad}

The statistical data already presented show that different training areas are treated differently and unequally by the market, with graduates from some areas being more 'employable' than others. This will certainly have consequences on the life trajectories of individuals and may contribute to explain the fact that labour demand abroad for higher education graduates is situated mostly in those areas of education/training, whose graduates are less absorbed by the domestic market. See Table 5.

\section{The brain drain research: preliminary results}

Interviews were conducted with seven focus groups (27 individuals). The analysis considers the reasons put forward for mobility within the European area, and the temporal characteristics of mobility (permanent or temporary, long term or transitory). 


\section{Pull and push factors}

What are the reasons that lead qualified individuals to leave their country of origin? What exists in other countries that Portugal lacks? The factors presented by respondents for their exodus are related to three main aspects: (a) the crisis of the labour market in Portugal offers few opportunities for skilled work; (b) the work content does not always effectively use the skills attained and certified by the educational system and (c) the desire to accumulate internationalisation capital. Most respondents expressed the idea that they could not find, in Portugal, satisfaction and professional achievement, or cognitive and professional stimuli critical to the development of the career they pursued.

As can be perceived through these testimonies, emigration appears as a way of 'doing what one likes', of developing a career and projecting it internationally. However, the existence of better job opportunities in destination countries is also quite stressed, giving emigrants a greater sense of stability and job security, insofar as there are more options.

Other motivations leading to emigration, although at a secondary level, are related to emotional, personal or family autonomy factors.

\section{Long term or transitory mobility}

One of the aspects that may determine the loss of human capital in the country of origin is the duration of the emigration period. When a person emigrates, does that person consider that decision to be a temporary or a long term? Is it a project for life or for a short term? Does the mobility period lived meanwhile change the initial view? Why?

Most respondents stated that the prospect of mobility is, at least, in the medium term and although they were initially contemplating a transient solution, the experience lived in the meantime changed the plans for a bigger migration period.

The idea of a temporary emigration has given rise to a long-term emigration. Opportunities found, together with the feeling of not getting the same in Portugal, are the most frequently mentioned reasons for this shift. Transient emigration out of Portugal is also a scenario that is now regarded more naturally.

Respondents' expectations about the future imply, thus, a long-term stay abroad. The idea that they would return to Portugal in the short term only for some reason of family emergency or for some irresistible employment offer is recurrent among respondents.

\section{Final remarks}

The above analysis for the Portuguese case demonstrates well the different theoretical positions referenced above: higher levels of education are more rewarded by the labour market; and different areas of education and training are treated differently by the market, denouncing various levels of employability. That situation allows us to state that in Portugal, human capital, segmentation and social reproduction theories can still be observed very clearly in the way the market treats students of different ages, academic degrees and areas of study differently, considering the employability 'rate' of those students. 
The higher education unemployment rate is always less than the total, but the number of unemployed higher education graduates has grown significantly in recent years. As a result, graduates have sought employment outside of Portugal and the flow of emigration in recent years is higher among the more skilled than in the total population.

In these circumstances, it is likely that brain drain could be a serious problem for the country's development and the loss of the generation with the highest qualifications and competence. This fact reveals some important questions the country must resolve, namely the crisis of the labour market which offers few opportunities for skilled work and the fact that the work content does not always effectively require the use of the skills attained and certified by the educational system. Until now, the country risks losing the more qualified individuals and the continuous diminution of the number of individuals enrolled in higher education.

Of course, this risk can be mitigated by highly qualified immigrants who have come into Portugal in recent years. However, the lack of consistent data on these immigration flows does not allow for their impact on the country to be predicted. The only certainty that can be taken is that Portugal attends to the issues surrounding the emigration of a number of higher education graduates whose skills will be used by the countries hosting them.

\section{Disclosure statement}

No potential conflict of interest was reported by the authors.

\section{Funding}

This paper was developed under the project BRADRAMO (Brain Drain and Academic Mobility from Portugal to Europe) financed by the FCT - Fundação para a Ciência e Tecnologia, (the principal state financing agency, PTDC/IVC-PEC/5049/2012).

\section{References}

Becker, G. (1964). Human capital - A theoretical and empirical analysis, with special reference to education. New York: Columbia University Press.

Beine, M., Docquier, F., \& Rapoport, H. (2003). Brain drain and LDC's growth: Winners and losers (Discussion Paper no 819). Bonn: Institute for the Study of Labor (IZA).

Beine, M., Docquier, F., \& Rapoport, H. (2008). Brain drain and human capital formation in developing countries: Winners and losers. The Economic Journal, 118, 631-652. doi:10.1111/ j.1468-0297.2008.02135.x

Boudon, R. (1973). L'inégalité des chances. Paris: Pluriel.

Bourdieu, P., \& Passeron, J.-C. (1964). Les héritiers. Paris: Les Éd. Minuit.

Bourdieu, P., \& Passeron, J.-C. (1970). La reproduction. Paris: Les Éd. Minuit.

Cabrito, B. (2002). O financiamento do ensino superior: Condição social e despesas de educação dos estudantes universitários em Portugal. Lisboa: EDUCA.

Cardoso, J., Escária, V., Ferreira, S., Madruga, P., Raimundo, A., \& Varanda, M. (2012). Empregabilidade e ensino superior em Portugal. Lisboa: A3ES Readings.

Castles, S., \& Miller, M.J. (2003). Age of migration: International population movements in the modern world. Basingstoke: Palgrave Macmillan. 
Cerdeira, L. (2009). O financiamento do ensino superior Português. A partilha de custos. Lisboa: Almedina.

Cerdeira, L., Cabrito, B., Patrocínio, J., Machado, M.L., \& Brites, R. (2012). Projecto CESTES. Custos de educação dos estudantes do ensino superior Português. Lisboa: EDUCA.

Clark, B. (1998). Creating entrepreneurial universities: Organizational pathways of transformation. Oxford: IAU Press \& Elsevier Science Ltd.

Collins, R. (1979). The credential society: A historical sociology of education and stratification. New York: Academic Press.

Docquier, F., Faye, O., \& Pestieau, P. (2008). Is migration a good substitute for education subsidies? Journal of Development Economics, 86, 263-276. doi:10.1016/j.jdeveco.2007.12.007

Docquier, F., \& Marfouk, A. (2006). International migration by educational attainment (19902000). In C. Ozden \& M. Schiff (Eds.), International migration, remittances and the brain drain (5th ed.). Washington, DC: Palgrave-Macmillan.

Hamilton, K. (2003). Migration and development: Blind fact and hand-to-find facts. Migration Policy Institute. Retrieved from http://www.migrationpolicy.org/article/migration-and-devel opment-blind-faith-and-hard-find-facts

Heuer, N. (2011). The effect of occupation-specific brain drain on human capital (Working Papers in Economic and Finance no 7). Tubingen: University of Tubingen.

Johnson, J.M., \& Regets, M. (1998). International mobility of scientists and engineers to the USbrain drain or brain circulation? NSF Issue Brief, June, 98-316.

Martínez, D., Mora, J., \& Vila, L. (2007). Entrepreneurs, the self-employed and employees amongst young European higher education graduates. European Journal of Education, 42, 99-117. doi:10.1111/ejed.2007.42.issue-1

Meyer, J.-B. (2001). Network approach versus brain drain: Lessons from the diaspora. International Migration, 39, 91-110. doi:10.1111/imig.2001.39.issue-5

Mora, J.-G., \& Nugent, M. (1998). Seeking new resources for European universities: The example of fund-raising in the US. European Journal of Education, 33, 113-129.

Nugent, M. (2004). The transformation of student career. New York: Routledge Falmer.

Olesen, H. (2002). Migration, return and development: An institutional perspective. International Migration, 40, 125-150. doi:10.1111/imig.2002.40.issue-5

Pizarro, J.M. (2005). Globalizados, pero restringidos. Una visión latinoamericana del mercado global de recursos humanos calificados. Santiago de Chile: Centro Latinoamericano y Caribeno de Demografia.

Prost, A. (1992). L'enseignement s'est-il démocratisé? Paris: P.U.F.

Schultz, T. (1961). Investment in human capital. American Economic Review, 51, 1-16.

Spence, M. (1973). Job market signaling. The Quarterly Journal of Economics, 87, 355-374. doi:10.2307/1882010

Willis, P. (1977). Learning to labour. How working class kids get working class jobs. Aldershot: Gower Publishing. 